\title{
Investigating a PC-based Student-made Application and Its Implementation in Young Learners' Classroom
}

\author{
Ida Zuraida Supri*, Ervina C. M. Simatupang, Hendar \\ Department of English, Widyatama University, Indonesia
}

Copyright $@ 2019$ by authors, all rights reserved. Authors agree that this article remains permanently open access under the terms of the Creative Commons Attribution License 4.0 International License

\begin{abstract}
Games are inseparable in young learners' classes. One of the reasons they are employed in the classroom is due to young learners' short attention span (Brown: 2000, Harmer: 2002). Games are inserted in learning process to sustain young learners' interest and to make them focus on the topic learned. Cross (1992) accentuates that games reduce tension by adding fun and humor to lessons and they add an element of competitiveness that motivates learners to participate. Furthermore, Read (2007) states that games provide stimulation, variety, interest and motivation. It is evident that games are beneficial for young learners' learning. They allow students to actively involve both physically and cognitively which may reduce boredom in learning. However, there only few game applications, specifically, Personal Computer (PC) game available for teachers to use which can support young learners learning English. Some established English learning websites provide games for young learners but the number is still limited. Concurrently, a student from Informatics Engineering of Widyatama University worked on his course project on building PC games applications for children. The PC game applications were then used in young learners' class. Therefore, this paper will discuss 1) the PC-based- games made by student in terms of the attendance of young learners' characteristics of learning, 2) the implementation of using the above game applications, and 3) Young learners' responses to the game applications.
\end{abstract}

Keywords Young Learners, Games, Learning

\section{Introduction}

Young learners learn differently from those of adults do. Therefore, teacher should employ different approaches when teaching them; teacher should consider learners' cognitive and physical activities to facilitate their characteristics of learning. Fun and enjoyable atmosphere is important to retain their attention. One of the ways to do is by employing games. According to Oxford Advanced Learner's dictionary games are activity people do to have fun. It is believed that games reduce tension by adding fun and wittiness to lessons and they add an element of competitiveness that motivates learners to participate (Cross: 1992). Games have been utilized in young learners' classes because they provide stimulation, variety, interest and motivation Read (2007).

Children are aware of using PC, internet, or tablets, smart phones for many activities, such as browsing over their interest topics, downloading or uploading materials, playing games and others (Eleje, Abanobi \& Obasi, 2017; Deacon \& Van Rensburg, 2018; Dierker, et.al.2018; Donkor \& Waek, 2018; Dori, 2018; Jabarullah and Hussain, 2018). Games are media or activities children love to do. Unfortunately, there is limited source of games facilitating young learners learning English either for classroom or personal use.

This research was initiated when a student from Informatics Department came for a topic for his field study project. Having the above constraints in providing suitable games for teaching young learners, he was suggested to develop a PC-based game. The idea was creating a picture dictionary and a picture cross word puzzle.

\section{Methods}

This research employed a naturalistic qualitative research method; that the classroom activities were not manipulated or interfered. Paton (2001) as quoted in Golafshani (2003) asserts that qualitative research employs a naturalistic approach that inquire about understanding phenomena in context-specific settings such as 'real world setting' where the researcher does not attempt to manipulate the phenomenon of interest. Thus, the focus is on the observation, describing, and understanding what the students did and felt while playing the games in the classroom. 
Descriptive inductive analytical approach is applied in this study. The general patterns of data analysis were a simultaneous action during the data collection stage. In the observation method it is suggested that the analysis is carried out as soon as the observation finishes (Maxwell, 1996), otherwise it will lose visual details that might be important and they might be forgotten if it waits to be analyzed at a later time. Data obtained from observations, and interviews were triangulated to see that the data showed consistency. Then, conclusions could be drawn.

The Objects of this research are the games. There are two types of games; a picture dictionary and a picture crossword puzzle. The dictionary has a vocabulary entry, a picture and sound of how to pronounce the word. A picture crossword puzzle is like generic crossword puzzles. Instead of giving word problems, this one provides pictures on the sheet of the crossword puzzle.

The study utilized a set of procedures to obtain the data. The first step is conducting an observation and on the picture dictionary and crossword a puzzle to see what young learners' learning characteristics are attended, categorizing then analyzing them. The second is conducting classroom observation when the two games are implemented in English for Children (EC class), Note taking on the activities occurred, focusing on your learner responses. The last step is conducting interviews. Triangulation is essential in order to have consistency in the findings of the research.

\section{Theoretical Reviews}

Learning mother language is a slow process for children at home. As a result, they need time and conducive atmosphere in learning foreign language. On top of that, the process of learning should facilitate their character of learning since they learn differently from those of adults do (Fujioka, et.al. 2016; Garba, 2017; Ettien, 2018; Foulidi, et.al. 2018; Garaeva \& Ahmetzyanov, 2018; Jabarullah and Hussain, 2019; Allam, 2018; Andriansyah et al., 2018; Manzuma-Ndaaba et al., 2018; Bagherpour \& Shamshiri, 2018; Tayebi et al., 2019). They have their own unique characteristics of learning. Musthafa (2002) argues that they have their own culture and preferences in learning language. Firstly, they learn better when learning involves their physical experience; hands on experience. Learning should rivet their five senses because their understanding does not only come from teacher's explanation but from but also from what they see, feel, smell, touch and hear. Going through this experience and interaction using their senses allow them to absorb materials taught in class (Harmer: 2002:38, Scott and Ytreberg: 1990:2) and Shin: 2006:3). The implication, the learning should be designed by involving their sensory aids. Using multimedia may improve their understanding since it presents audio and visual (Harmer: 2002, Ellis and Brewster: 2002:204,
Stempleski: 1990:5, Gersten and Tlustý: 1998, cited from Richard-Amato: 2003, Mayora: 2006, Ishihara and Chi: 2004, and Ambrose: 2002).

The second character of young learners is they love to talk about themselves. Nunan (2002) elaborates that young learners are keen to talk about themselves, and respond well to learning which uses themselves and their own lives as main topics in the classroom. Therefore, choosing topics within their prior knowledge and giving sufficient demonstration is crucial. Topics like, family, friends, objects in the house, objects in the playground, food, fruit are suitable for them.

Another characteristic which should be noted is that young learners have limited attention span; unless activity are extremely engaging they can easily get bored, losing interest after several minutes of the activity Nunan (2002), Brown (2002) and Shin (2006). They are centered to here and now, on the functional purposes of language. Therefore, tasks given should be calculated to capture their immediate interest (Brown, 2000). Shin (2006) states that capturing their attention and keep them engaged in activities is to add the activities with lots of brightly colored visual, toys, puppet, or objects to match the one used in stories that you tell or songs that you sings.

The fourth character is that young learners often learn indirectly rather than directly (Brown: 2002). This means that they absorb information from all sides, learning from everything around them rather than focusing on the precise topic. And they generally demonstrate enthusiastic manner for learning and a curiosity about the world around them. Having enthusiastic manner and a curiosity about the world is one positive learning attitude. Therefore, teacher should provide tasks accelerating their learning English from the surrounding, for example by asking them to write objects they find on the way home in English, listen to song, watch films, play games, etc.

The fifth character is young learners learn better when learning is employing whole language approach, meaningful, interesting and functional; whereas adult learn from parts to whole; they learn words, phrases, sentence constructing, (Brown 2002). They tend to learn things holistically in the form of script, like such as going to a market, in school, family, etc. Building on this theory, in the case of learning English as a foreign language, children will find it easy if it is embedded in play, such as story lines, or real life conversation. Providing them video may be useful because generally they are presented in topic (Ishihara and Chi: 2004, Ambrose 2002). Giving lesson packed in a particular topic may help them understand and focus on what they are learning.

The sixth character is young learners can cope with one thing at a time without much difficulty. Teaching or presenting a lot of things to them at the same time may cause frustration and failure, either to the children or the teachers. Sinaga (1997) proposes when teaching 'likes and dislikes', for example, a teacher does not have to use all the 
subjects at once as it is possible to be done in adult classes. He should limit based on their timely need (I and You first then next session followed by He and She). This is in line with Shin (2006:4) that it is highly recommended to teach the lessons in themes. Thus, it is clear that young learners learn one thing at a time.

It is obvious that young learners pick up new things easily and quickly, but at the same time forget them quickly. The seventh character of young learners is they learn fast and forget quickly. This is because they have a relatively weak long-term memory. To facilitate this learning character, Shin (2006:4) suggests that moving from one activity to others that are related in content and language helps to recycle the language and reinforce students' understanding and use of it. Sinaga (1997) also lesson should be recycled and children should be reminded frequently of what they have learned. Well's, as quoted by Ashworth and Wakefield (2005), also stated that knowledge cannot be transmitted in isolation, but must be reinvented as the learner brings to each new situation his own previous experience and background and interprets new information from that perspective.

Moreover, young learners' learning is a process, not merely a product. The process of learning can be accelerated or enhanced by breaking learning into stages and providing building blocks which connect these together (Bruner 1983 as cited from Ellis and Brewster 2002)

Interpreting the above idea, the teacher should recycle lesson and frequently remind of what they have learned. Reappearing vocabulary or simple grammar presented in the previous activity in the next activities is a method to recycle the materials. Giving lesson in stages is one way to assist them learning better.

Young learners cannot be expected to sit down and do a certain activity for a long time. Activities should be designed to capture their interest, short, and varied to allow a change of mood on the part of the children. According to Ellis and Brewster (2002:162) song is an ideal vehicle for language learning because young learners love songs and sing songs are fun for them. They also added that letting young learners watch video or film also is another way to vary activities in order to capture and maintain their interest.

It can be inferred that giving variation of interesting activities may allow young learners to learn language. Once an activity captures their interests they may be willing to learn (Ahmed, Umrani, Qureshi \& Sarmad, 2018; Ali \& Haseeb, 2019; Haseeb, Abidin, Hye, \& Hartani, 2018; Haseeb., 2019; Suryanto, Haseeb, \& Hartani, 2018).

Borrowing Harmer's words (2002), young learners respond to meaning even if they do not understand individual word. When they get involved in a conversation and the topic is within their language capacity and they get enough exposure on that particular theme they will fairly be able to respond. With skillful guidance from and the understanding of teachers, children's language continues to grow and blossom.

It can be concluded that young learners are risk takers in learning language. They would try out their language ability. It is a task of a teacher to guide and get them exposed with target language. Thus their English will improve.

\section{Findings and Discussions}

\subsection{Game Application Observation Results}

The PC-based-games made by the students has attended four young learners' learning character, namely 1 . Learn when kept as a whole, 2. Fun learning, 3. Learn fast forget quickly, and 4 . One thing at a time.

Learning when kept as a whole concerns the way young learners learn target language holistically. Young learners learn best when learning is kept whole (whole language approach), meaningful, interesting and functional; as opposed to adult who learn from parts to whole; they learn words, phrases, sentence constructing, (Brown, 2002). In line with Brown's words, Musthafa (2002) also states that young learners tend to learn things holistically in the form of script (such as going to a market, going to school, family, etc.). This learning characteristic is attended by the games. This learning characteristic is presented in the game application since each game has a theme. The picture dictionary focuses on two themes, animals and fruits, while the crossword puzzle focuses on vocabulary on objects and occupations.

The second characteristic attended is fun learning. This characteristic concerns with young learners' willingness to learn when the lessons are presented in interesting ways. The availability of pictures, background music and colors provide interest to learners. Games are connected with competition, eagerness to deal with it in order to win. This application provides those excitements in the learning.

In picture dictionary for instance, learners are challenged to identify the picture displayed on the screen (see picture 2). Then, they may check whether or not what they have identified is correct or not by pushing sound button. The pronunciation will be given as well as the spelling of the words. 


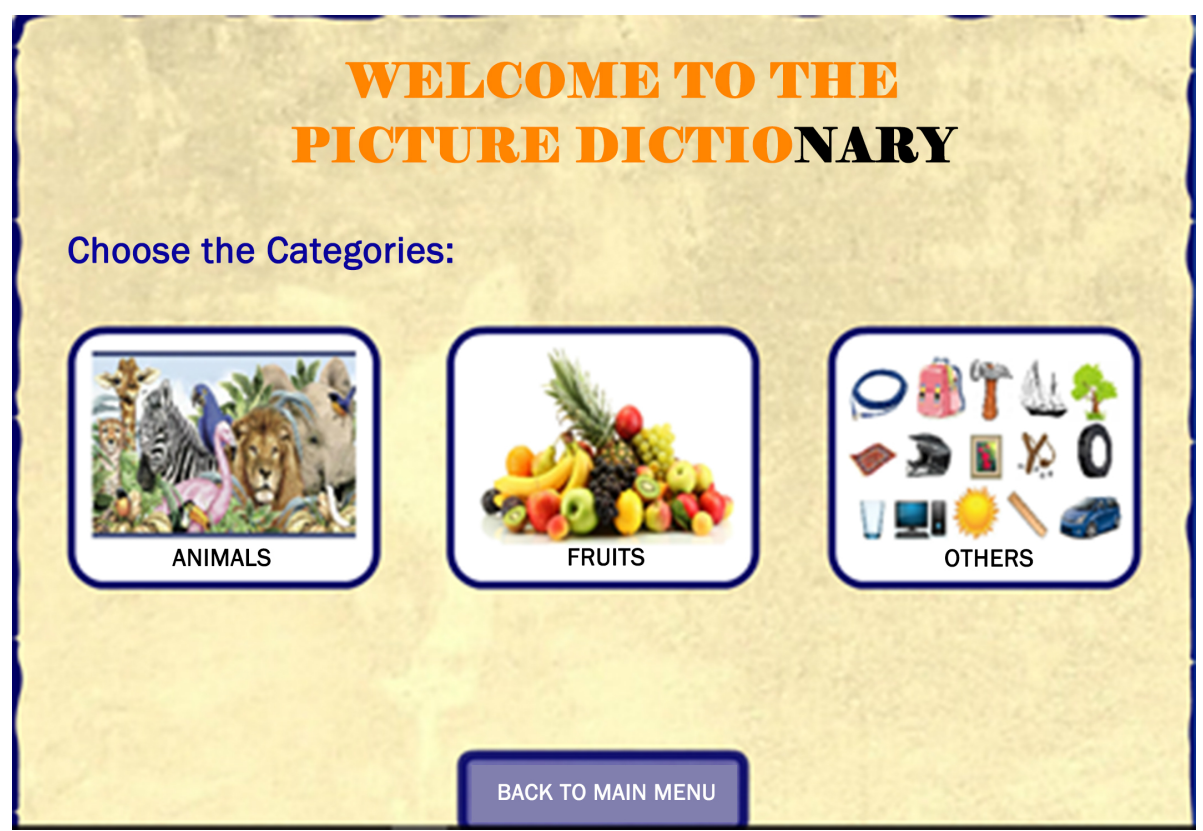

Picture 1. Dictionary opening page

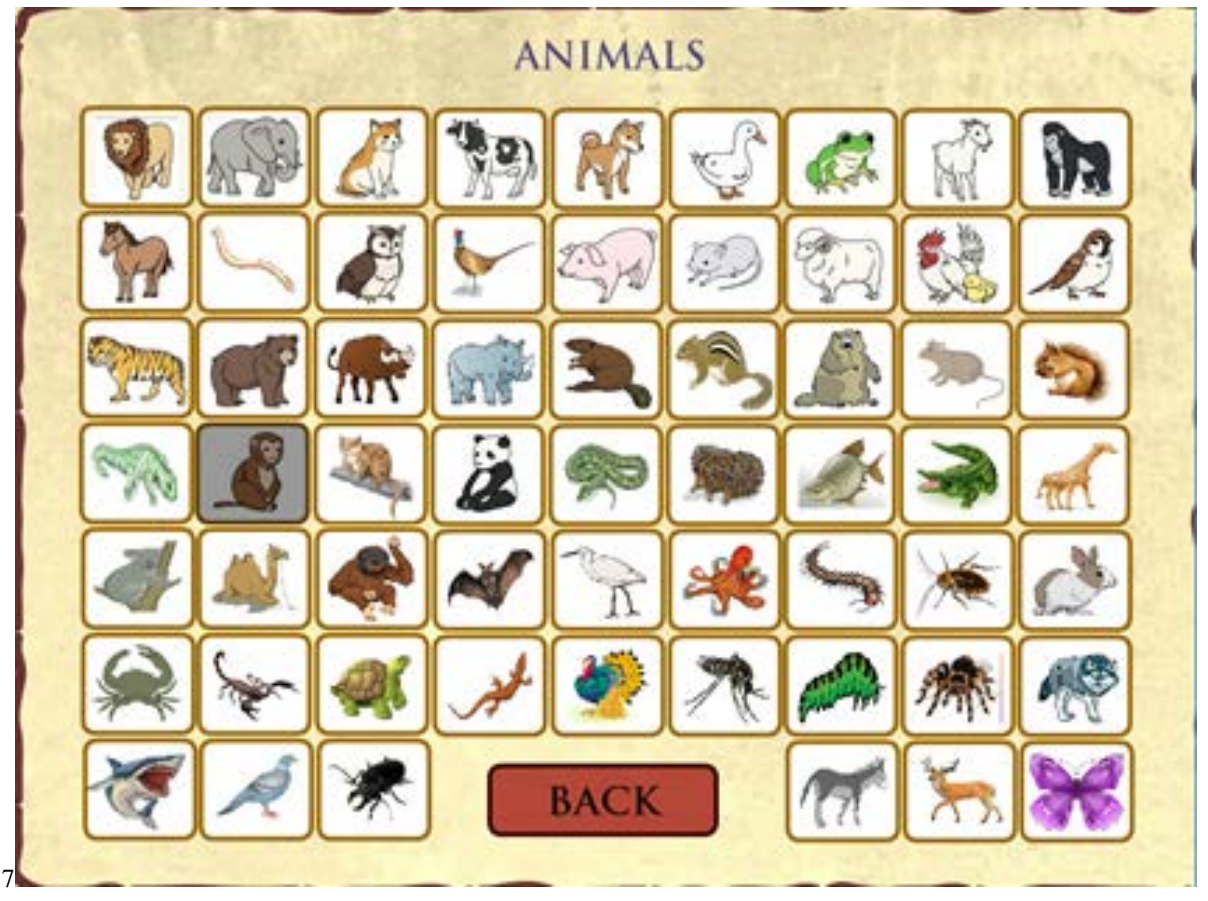

Picture 2. Picture entry 


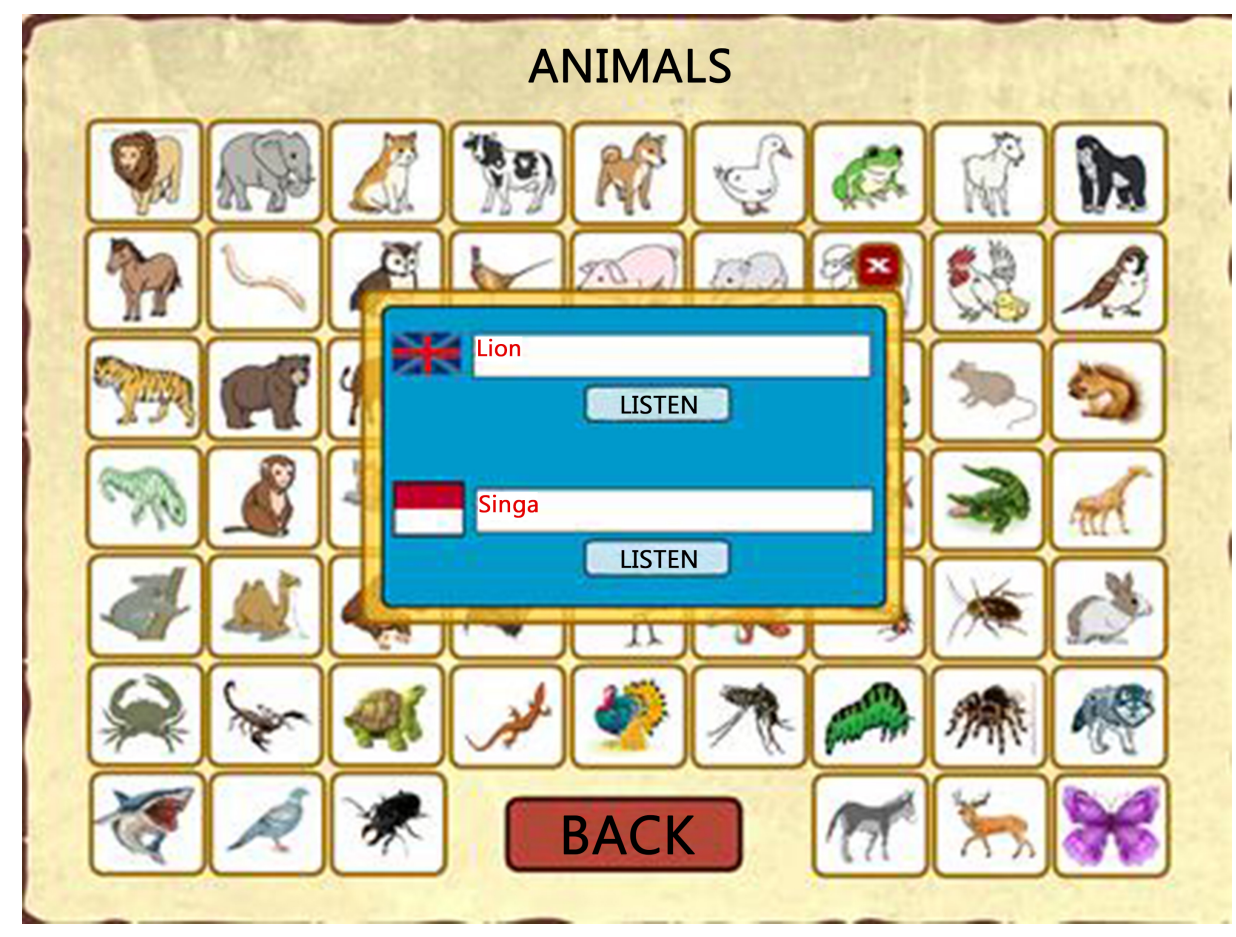

Picture 3. Sound (pronunciation) in English and Bahasa Indonesia

The third learning characteristic is young learners learn fast but forget quickly. Providing recycling materials in the learning may allow learners to maintain what they have learned both in their short and long term memory. This game application allows them to play the game and replay it. Even in the classroom it is possible to do as long as the teacher understands the know-how of the best time in inserting it in the classroom activities.

Finally, is one thing at a time learning characteristic. This has been accommodated in the picture dictionary by presenting the dictionary in topics; fruits, animals, and things/objects.

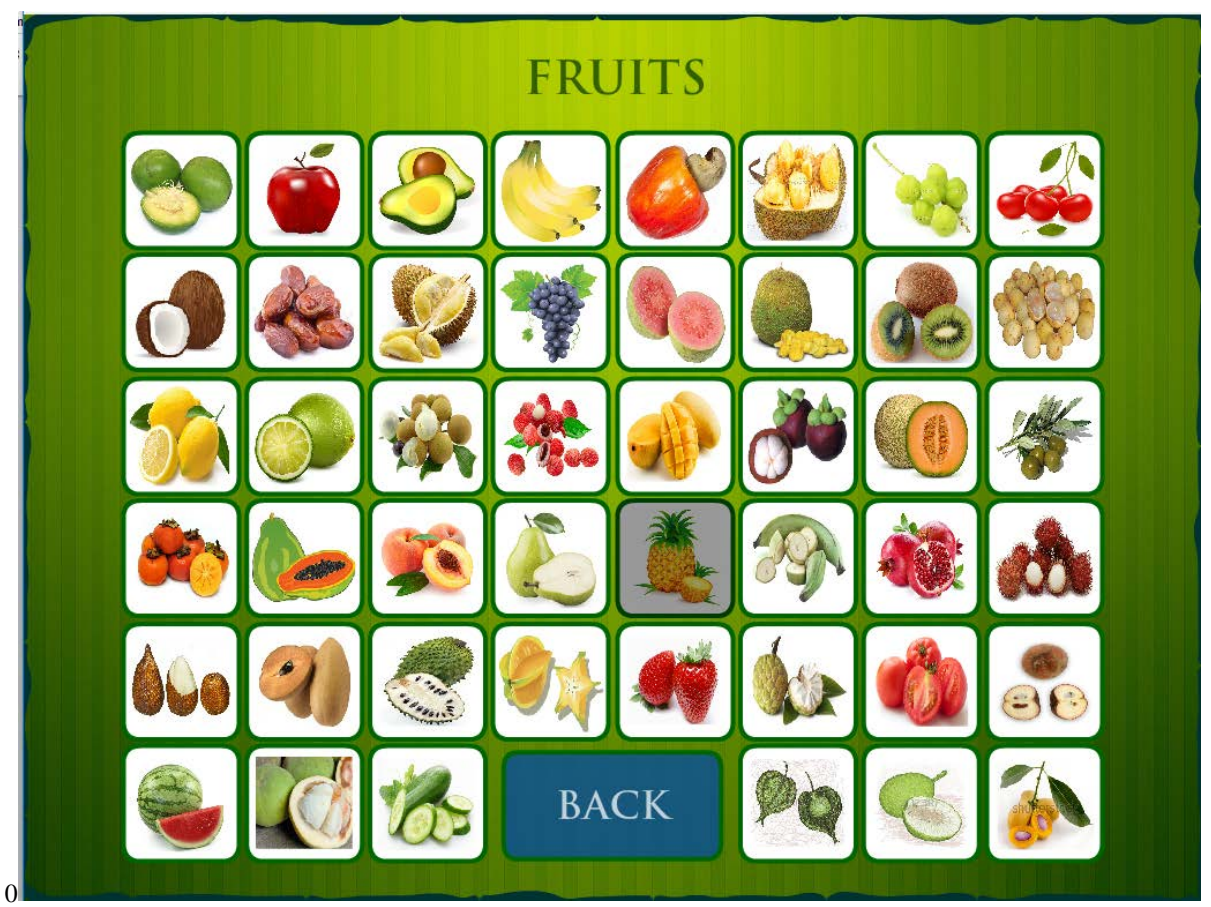

Picture 4. Fruit page of picture dictionary 
Providing specific topic eases young learners to focus on their learning. Picture 4 shows vocabulary on fruits. Learners may start identifying their favorite fruits or fruit they don't like. Connecting what they learn to their real life experience may lead to long retention learning.

\subsection{Implementation of Using the Game Applications}

The two games were given in the classroom as a supplementary activity, as a vocabulary enhancement. This activity was given at end of the session before the class ended. The class was divided into four groups. Then, they have to compete to identify and to pronounce as many words in the dictionary game correctly. They were hilariously involved in the game. Similarly, the crossword puzzle game also gained positive response. Young learners love competition. This activity allows them to compete in a fun way in groups. They learned to work together to solve problems in the crossword puzzle (see picture 5 and 6). All in all, the two games acquire positive response from the learners.

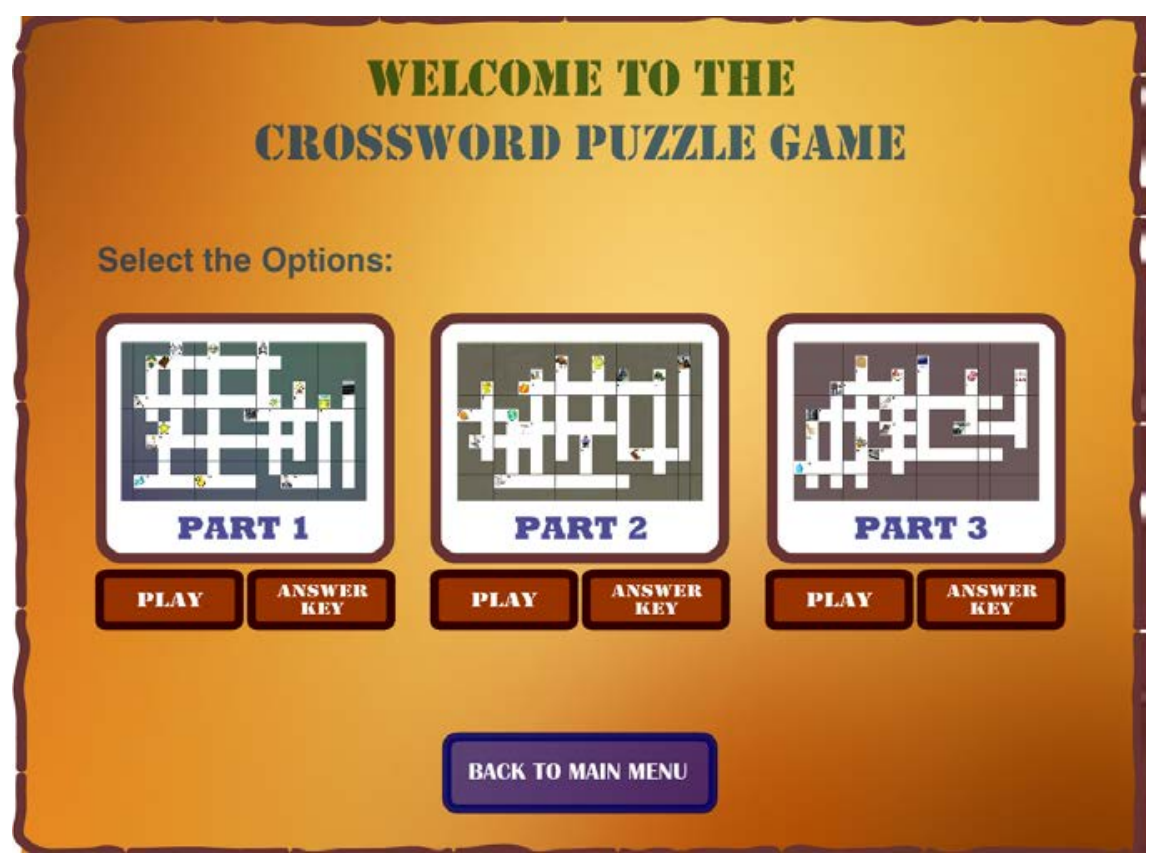

Picture 5. Opening page of the crossword puzzle

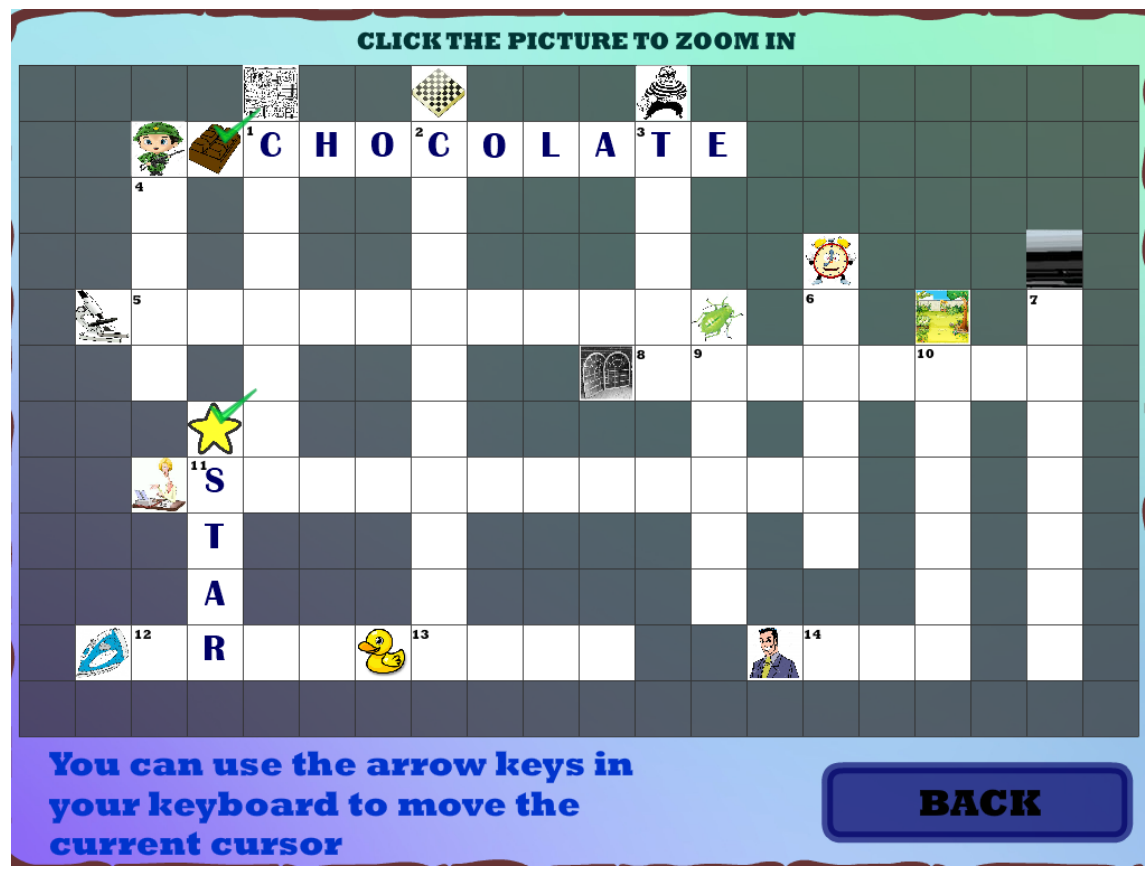

Picture 6. Picture crossword puzzle 


\subsection{Young Learners' Responses to the Game Applications}

After the class ended, the teacher (researcher) interviewed the students to directly get information from them about the PC-based game application. All students responded positively. The games were fun and they wanted to have the game longer in the class. Therefore, it can be concluded that learners enjoyed doing activities with the provided PC-based game application.

\section{Conclusions and Suggestions}

In general, the game applications have attended young learners 'learning characteristics; learning when kept as a whole, fun learning, learn fast and forget quickly, and one thing at a time. Those characteristics of learning have been accommodated so that when the games were given to young learners' class, positive response was exhibited by them. Enthusiasm, curiosity and engagement are forms of their willingness in getting involved in the classroom. One thing to highlight, games are just a tool to introduce or to enrich students' knowledge or skills. It is in the hand of the teacher's wisdom, as a facilitator or as a controller, in the classroom on determining how and when the game application may effectively be used in the classroom.

This pilot project between two majors; English Department lecturer and Student of Information Technology is a good initial to lead to further collaboration in developing PC-based applications for language learning, specifically, English. However, rigorous discussions are primary in achieving better approach on pedagogical applications for better quality of game applications.

\section{REFERENCES}

[1] Alwasilah, A. C. 2002. Pokoknya Kualitatif. Bandung: Pustaka Jaya.

[2] Amato, R. and Patricia, A. 2003. Making it happen: from interactive to participatory language teaching. New York: Longman

[3] Ashworth, M. \& Patricia, W. 2005.Teaching The World's Children ESL for Ages Three To Seven. English Teaching Forum.43 (1). (p.2-7)

[4] Brown, H. D. 2000. Teaching by Principles: An Interactive Approach To Language Pedagogy. New York: Longman

[5] Creswell, J.W. 1994. Research design: Qualitative \& Quantitative Approaches. California: Sage Publication, Inc.

[6] Deacon, E., \& Van Rensburg, E. (2018). Emotional and Social Competence in School Beginners: An Intervention Programme for Teachers and Therapists. American Journal of Education and Learning, 3(2), 85-92.
[7] Dierker, L., Flaming, K., Cooper, J. L., Singer-Freeman, K., Germano, K., \& Rose, J. (2018). Evaluating Impact: A Comparison of Learning Experiences and Outcomes of Students Completing A Traditional Versus Multidisciplinary, Project-Based Introductory Statistics Course. International Journal of Education, Training and Learning, 2(1), 16-28.

[8] Donkor, A. K., \& Waek, B. I. (2018). Community Involvement and Teacher Attendance in Basic Schools: The Case of East Mamprusi District in Ghana. International Journal of Education and Practice, 6(2), 50-63.

[9] Dori, N. (2018). The Dreyfus Affair and its Reflection in Ladino Literature. International Journal of Emerging Trends in Social Sciences, 3(2), 57-64.

[10] Eleje, L. I., Abanobi, C. C., \& Obasi, E. (2017). Development and Validation of Economics Achievement Test for Secondary Schools. Asian Journal of Education and Training, 3(1), 6-17.

[11] Ettien, A. (2018). A Study of Proctors' Involvement in National Examination Cheating: The Case of" Collège Privé MBF d'Abobo" Exam Center. Journal of Education and e-Learning Research, 5(1), 22-27.

[12] Fillmore, L. W. \& Catherine, S. 2000. What Early Childhood Teachers Need To Know About Language. Retrieved from http www.ericdigests.org/2001-3/early.htm

[13] Foulidi, X., Papakitsos, E. C., Papakitsos, E. C., Vamvakeros, X., \& Dimou, I. (2018). Teachers of Secondary Education and Professional Stress with Students Performance: A Geographical Case Study. Humanities and Social Sciences Letters, 6(3), 121-129.

[14] Fujioka, M., Hayashida, K., Saijo, H., Fukui, K., \& Ishiyama, S. (2016). Problems of International Committed Partnership Cooperation: A Successful Case of Reconstruction Surgery in Japan for Laotian Child with Severe Facial Anomaly. Humanities and Social Sciences Letters, 4(4), 77-83.

[15] Garaeva, A. K., \& Ahmetzyanov, I. G. (2018). Awareness of Historical Background as One of the Factors of Better Language Acquisition. International Journal of English Language and Literature Studies, 7(1), 15-21.

[16] Garba, A. S. (2017). Promoting Entrepreneurship Amidst Poverty and Unemployment: The Role of Nigerian Educational Policies. International Journal of Asian Social Science, 7(8), 684-695.

[17] Harmer, J. 2002. The Practice of English Language Teaching. Longman: Kualalumpur

[18] Jabarullah, N.H. and Hussain, H.I. (2018) Comparison of Higher TVET Education and 'Normal' Academic Education: The Determinants of Electrical Engineering Students' Performance, International Journal of Engineering \& Technology, 7 (4.29), 82-85.

[19] Jabarullah, N.H. and Hussain, H.I. (2019) The Effectiveness of Problem-Based Learning in Technical and Vocational Education in Malaysia, Education + Training, https://doi.org/10.1108/ET-06-2018-0129.

[20] Klein, K. 2012. Teaching Young Learners. English Teaching Forum, 31 (2) page 14 . Retrieved from http//exchanges.stategov/forum/vol2/vol31/no2/pg14/htm. 
[21] Latha, R. H. 2005. A reading program for elementary schools. English Teaching Forum, 43 (1). (18-23)

[22] Maxwell, J.A. 1996. Qualitative research design: An interactive approach. California: Sage Publication, Inc.

[23] Musthafa, B \& Wachyu, S. 1993. Teaching EFL learners sociolinguistics concepts for intercultural understanding. Retrieved from files.eric.ed.gov/fulltext/ED397661.pdf.

[24] Musthafa, B. 2002. EFL for young learners. Bandung: Crest.

[25] Paton, J. 2002. Fostering second language development in young children. ESL Articles Collection. Retrieved on 08/05/03 from http://www.1-language.com

[26] Pinter, A. 2006. Teaching young language learners. Oxford: Oxford University Press.

[27] Shin, J. K. 2006. Ten Helpful Ideas for Teaching English to Young Learners. English Teaching Forum, 44 (2).

[28] Sinaga, M. 1994. Teaching English to children (as opposed to adults) (p.173-178) Presented in National Seminar: The Development of TEFL in Indonesia. 1994

[29] Stempliski, S \& Barry, T. 1990. Video in action: Recipes for using video in language teaching. London: Prentice Hall.

[30] Strauss, A and Corbin J. 1990. Basic qualitative research: grounded theory procedures and techniques. New York: Sage Publication.

[31] Suyanto, K, K. E. 1999. Teaching English to young learners in Indonesia (p. 164-171). An article presented in National Seminar: The Development of TEFL in Indonesia. 1999.

[32] Allam, Z. (2018). Students' perception of quality in higher education: An empirical investigation. Management Science Letters, 8(5), 437-444.

[33] Andriansyah, A., Taufiqurokhman, T., \& Wekke, I. (2019). Responsiveness of public policy and its impact on education management: An empirical assessment from Indonesia. Management Science Letters, 9(3), 413-424.

[34] Manzuma-Ndaaba, N., Harada, Y., Nordin, N., Abdullateef, A., \& Rahim, A. (2018). Application of social exchange theory on relationship marketing dynamism from higher education service destination loyalty perspective. Management Science Letters, 8(10), 1077-1096.

[35] Bagherpour, M., \& Shamshiri, B. (2018). The effect of educational methods on creativity of pre-school children: A case study. Management Science Letters, 8(6), 717-724.

[36] Tayebi, S., Manesh, S., Khalili, M \& Sadi-Nezhad, S. (2019). The role of information systems in communication through social media.International Journal of Data and Network Science, 3(3), 245-268.

[37] Ahmed, U., Umrani, W. A., Qureshi, M. A., \& Samad, A. (2018). Examining the links between teachers support, academic efficacy, academic resilience, and student engagement in Bahrain. INTERNATIONAL JOURNAL OF ADVANCED AND APPLIED SCIENCES, 5(9), 39-46.

[38] Ali, A., \& Haseeb, M. (2019). Radio frequency identification (RFID) technology as a strategic tool towards higher performance of supply chain operations in textile and apparel industry of Malaysia. Uncertain Supply Chain Management, 7(2), 215-226.

[39] Haseeb, M., Abidin, I. S. Z., Hye, Q. M. A., \& Hartani, N. H. (2018). The Impact of Renewable Energy on Economic Well-Being of Malaysia: Fresh Evidence from Auto Regressive Distributed Lag Bound Testing Approach. International Journal of Energy Economics and Policy, 9(1), 269-275.

[40] Suryanto, T., Haseeb, M., \& Hartani, N. H. (2018). The Correlates of Developing Green Supply Chain Management Practices: Firms Level Analysis in Malaysia. International Journal of Supply Chain Management, 7(5), 316. 